\title{
The presence of a systemic inflammatory response predicts poorer survival in patients receiving adjuvant 5-FU chemotherapy following potentially curative resection for colorectal cancer
}

\author{
JEM Crozier*,', RF McKee', CS McArdle', WJ Angerson', JH Anderson', PG Horgan' and DC McMillan' \\ 'University Department of Surgery, Royal Infirmary, Glasgow G3I 2ER, UK
}

\begin{abstract}
There is increasing evidence that the presence of a systemic inflammatory response plays an important role in survival following curative resection for colorectal cancer. The present study evaluated the relationship between C-reactive protein concentrations and survival in a cohort of patients receiving adjuvant 5-fluorouracil (5-FU) chemotherapy following potentially curative resection for colorectal cancer. In all, 222 patients undergoing potentially curative resection for colorectal cancer were studied. Of these, 50 patients received adjuvant 5-FU-based chemotherapy. Circulating concentrations of C-reactive protein were measured prior to surgery. The minimum follow-up was 15 months; the median follow-up of the survivors was 38 months. During this period 61 patients died, 32 patients of their cancer and 29 of intercurrent disease. In those patients who did not receive adjuvant chemotherapy, age $(P<0.00 I)$, Dukes stage $(P<0.05)$ and an elevated $C$-reactive protein $(P<0.01)$ were significantly associated with survival. In those patients who did receive adjuvant chemotherapy, an elevated C-reactive protein concentration $(P<0.0 \mathrm{I})$ was significantly associated with survival. The presence of a systemic inflammatory response is an independent predictor of poor outcome in patients receiving adjuvant 5-FU-based chemotherapy following potentially curative resection for colorectal cancer.

British Journal of Cancer (2006) 94, 1833-1836. doi: I0.1038/sj.bjc.6603185 www.bjcancer.com

Published online 23 May 2006

(c) 2006 Cancer Research UK
\end{abstract}

Keywords: C-reactive protein; albumin; Dukes stage; 5-FU adjuvant chemotherapy; survival; colorectal cancer

Colorectal cancer remains the second commonest cause of cancer death in Western Europe and North America. Overall survival is poor; even in those patients who undergo potentially curative resection, more than one-third die within 5 years (McArdle and Hole, 2002). In view of these poor results there is increasing interest in the use of adjuvant chemotherapy.

Conventionally, in patients with primary operable colorectal cancer, the decision whether or not to offer adjuvant 5-fluorouracil (5-FU)-based chemotherapy is primarily based on the patient's age, pathological stage and fitness to tolerate chemotherapy. However, even in this selected cohort, the impact of chemotherapy on outcome is unpredictable. Therefore, there is continuing interest in prognostic factors that better reflect clinical outcome (Cascinu et al, 2003; Benson et al, 2004).

It has been demonstrated that the presence of a systemic inflammatory response, as evidenced by elevated circulating concentrations of C-reactive protein, is associated with increased recurrence and poor survival, independent of Dukes stage, in patients undergoing potentially curative surgery for colorectal cancer (McMillan et al, 1995, 2003; Nielsen et al, 2000). However, in these studies, few patients had received adjuvant chemotherapy.

It is therefore of considerable interest to examine whether this poor outcome might also be found in patients receiving adjuvant

*Correspondence: JEM Crozier; E-mail: joey@clinmed.gla.ac.uk Revised 19 April 2006; accepted 26 April 2006; published online 23 May 2006 chemotherapy. Indeed, an elevated C-reactive protein has recently been shown to be associated with poorer survival in patients receiving chemotherapy for advanced lung cancer (Forrest et al, 2004) and renal cancer patients (Bromwich et al, 2004).

Therefore, the aim of the present study was to evaluate the relationship between the systemic inflammatory response and survival in a prospective cohort of patients receiving adjuvant 5-FU chemotherapy following potentially curative resection for colorectal cancer.

\section{PATIENTS AND METHODS}

\section{Patients}

Patients with histologically proven colorectal cancer who, on the basis of laparotomy findings and preoperative abdominal computed tomography, were considered to have undergone a potentially curative resection between January 1999 and June 2004 at Glasgow Royal Infirmary were included in the study. The tumours were staged using conventional Dukes classification (Dukes and Bussey, 1958). Patients who had preoperative radiotherapy were excluded from the study since radiotherapy has been reported to evoke a systemic inflammatory response (Cengiz et al, 2001; Koc et al, 2003).

Patients were selected for 5-FU-based chemotherapy following discussion in the multidisciplinary group and taking into account 
tumour pathology, comorbidity and also patients' wishes. This was predominantly administered using the Mayo regimen for six cycles (O'Connell et al, 1997).

A blood sample was taken for routine laboratory measurement of $\mathrm{C}$-reactive protein measurement immediately prior to surgery. The limit of detection of the assay was a C-reactive protein concentration lower than $6 \mathrm{mgl}^{-1}$. The coefficient of variation, over the range of measurement, was $<5 \%$, as established by routine quality-control procedures. At this time no patient showed clinical evidence of infection or other inflammatory condition.

The study was approved by the Research Ethics Committee, Royal Infirmary, Glasgow.

\section{Statistics}

Comparisons between groups of patients were carried out using contingency table analysis $\left(X^{2}\right)$ as appropriate. Grouping of the variables age and $\mathrm{C}$-reactive protein was carried out using standard thresholds (O'Gorman et al, 2000; Scottish Cancer Intelligence Unit, 2000). Survival analysis of the group variables was performed using the Cox proportional hazard model. Deaths up to 31st August 2005 were included in the analysis. Multivariate survival analysis, including all covariates was performed using a stepwise backward procedure to derive a final model of the variables that had a significant independent relationship with survival. To remove a variable from the model, the corresponding $P$-value had to be $>0.10$. Analysis was performed using SPSS software (SPSS Inc., Chicago, IL, USA).

\section{RESULTS}

Two hundred and twenty-two patients undergoing potentially curative resection for colorectal cancer were studied (Table 1). The majority of patients were aged 65 years or more, had colonic tumours and had C-reactive protein concentration in the normal range $\left(\leqslant 10 \mathrm{mg} \mathrm{l}^{-1}\right)$ prior to surgery.

Of the 222 patients, 50 received adjuvant 5-FU-based chemotherapy (Table 1). Those patients who received chemotherapy were younger $(P<0.001)$, more likely to be male $(P<0.10)$, were more likely to have Dukes $C$ disease $(P<0.001)$ and did not have hypoalbuminaemia $(P \leqslant 0.01)$. The groups were similar in terms of site and $\mathrm{C}$-reactive protein concentration.

The minimum follow-up was 15 months; the median follow-up of the survivors was 38 months. During this period 61 patients died, 32 patients of their cancer and 29 of intercurrent disease. On univariate survival analysis, in those patients who did not receive adjuvant chemotherapy, age $(P<0.001)$, Dukes stage $(P<0.05)$ and an elevated $C$-reactive protein $(P<0.01)$ were significantly associated with survival (Table 2). In those patients who did receive adjuvant chemotherapy, an elevated C-reactive protein concentration $(P<0.01)$ was significantly associated with survival.

On multivariate survival analysis, in those patients who did not receive adjuvant chemotherapy, age $(P<0.05)$ and an elevated $\mathrm{C}$ reactive protein $(P<0.05)$ were independently associated with

Table I Clinicopathological characteristics in patients undergoing potentially curative surgery with and without adjuvant 5-FU chemotherapy for colorectal cancer

\begin{tabular}{|c|c|c|c|}
\hline & No adjuvant 5-FU & Adjuvant 5-FU & $P$-value \\
\hline & $172(\%)$ & $50(\%)$ & \\
\hline \multicolumn{4}{|l|}{ Age group (years) } \\
\hline$<65$ & $40(23)$ & $26(52)$ & \\
\hline $65-74$ & $58(34)$ & $18(36)$ & \\
\hline$\geqslant 75$ & $74(43)$ & $6(12)$ & $<0.001$ \\
\hline \multicolumn{4}{|l|}{ Sex } \\
\hline Male & $88(5 \mathrm{l})$ & $33(66)$ & \\
\hline Female & $84(49)$ & $17(34)$ & 0.064 \\
\hline \multicolumn{4}{|l|}{ Site } \\
\hline Colon & $100(58)$ & $28(56)$ & \\
\hline Rectum & $72(42)$ & $22(44)$ & 0.788 \\
\hline \multicolumn{4}{|l|}{ Dukes stage } \\
\hline A & $23(13)$ & $0(0)$ & \\
\hline B & $96(56)$ & $9(18)$ & \\
\hline C & $53(31)$ & $41(82)$ & $<0.001$ \\
\hline \multicolumn{4}{|l|}{ C-reactive protein } \\
\hline$\leqslant \mid 0 \mathrm{mg}^{-1}$ & $95(55)$ & $32(64)$ & \\
\hline$>\left.10 \mathrm{mg}\right|^{-1}$ & $77(45)$ & $18(36)$ & 0.270 \\
\hline \multicolumn{4}{|l|}{ Albumin } \\
\hline$\geqslant 35 \mathrm{gl}^{-1}$ & $132(77)$ & $45(90)$ & \\
\hline$<35 \mathrm{gl}^{-1}$ & $20(12)$ & $0(0)$ & 0.01 \\
\hline Alive & $126(74)$ & $35(70)$ & \\
\hline \multicolumn{4}{|l|}{ Dead } \\
\hline Cancer specific & $23(13)$ & $9(18)$ & \\
\hline Intercurrent & $23(13)$ & $6(12)$ & 0.709 \\
\hline
\end{tabular}

Table 2 Clinicopathological characteristics in patients undergoing potentially curative surgery and adjuvant 5-FU chemotherapy for colorectal cancer $(n=222)$ and survival

\begin{tabular}{|c|c|c|c|c|}
\hline & No adjuvant chemotherapy $(n=172)$ & & Adjuvant chemotherapy $(n=50)$ & \\
\hline & HR (95\% Cl) & $P$-value & HR $(95 \% \mathrm{CI})$ & $P$-value \\
\hline \multicolumn{5}{|l|}{ Univariate analysis } \\
\hline Sex (male/female) & $1.37(0.77-2.46)$ & 0.287 & $1.55(0.55-4.36)$ & 0.411 \\
\hline Site (colon/rectum) & $1.23(0.69-2.21)$ & 0.477 & $1.19(0.43-3.29)$ & 0.735 \\
\hline Dukes stage $(\mathrm{A} / \mathrm{B} / \mathrm{C})$ & $1.75(1.06-2.89)$ & 0.029 & $3.36(0.44-25.85)$ & 0.245 \\
\hline C-reactive protein $\left(\leqslant 10,>10 \mathrm{mg}^{-1}\right)$ & $2.39(1.32-4.34)$ & 0.004 & $6.68(2.05-21.72)$ & 0.002 \\
\hline \multicolumn{5}{|l|}{ Multivariate analysis } \\
\hline Age $(<65 / 65-74 / \geqslant 75)$ years & $1.87(1.13-3.09)$ & 0.015 & $1.21(0.47-3.15)$ & 0.693 \\
\hline Sex (male/female) & $1.08(0.55-2.09)$ & 0.828 & $0.92(0.26-3.22)$ & 0.894 \\
\hline Site (colon/rectum) & $1.57(0.81-3.07)$ & 0.185 & $1.15(0.31-4.27)$ & 0.834 \\
\hline Dukes stage (A/B/C) & $1.39(0.82-2.36)$ & 0.219 & $2.56(0.3 \mid-21.21)$ & 0.384 \\
\hline C-reactive protein $\left(\leqslant 10,>10 \mathrm{mg}^{-1}\right)$ & $2.10(1.04-4.25)$ & 0.039 & $5.57(\mid .32-23.51)$ & 0.019 \\
\hline Albumin $\left(\geqslant 35 /<35 \mathrm{gl}^{-1}\right)$ & $1.18(0.48-2.88)$ & 0.721 & & \\
\hline
\end{tabular}


survival (Table 2). In those patients who did receive adjuvant chemotherapy, an elevated C-reactive protein concentration $(P<0.05)$ was independently associated with survival.

\section{DISCUSSION}

In the present study, an elevated C-reactive protein concentration was associated with poorer survival, independent of age and Dukes stage, in patients receiving adjuvant chemotherapy following potentially curative resection for colorectal cancer. These results would suggest that the systemic inflammatory response, as evidenced by an elevated C-reactive protein concentration, is an important factor in determining outcome in patients receiving adjuvant 5-FU-based chemotherapy.

The basis of the relationship between the systemic inflammatory response and poor survival in patients undergoing potentially curative resection for colorectal cancer is not clear. The presence of an elevated C-reactive protein concentration may simply reflect a nonspecific inflammatory response secondary to tumour necrosis or local tissue damage. However, these elevated C-reactive protein concentrations do not appear to resolve following potentially curative surgery in the majority of patients (McMillan et al, 2003). Also, an elevated C-reactive protein concentration 3-6 months following curative resection also has independent prognostic value (McMillan et al, 1995, 2003). Therefore, these data suggest that the systemic inflammatory response participates in the progression of metastatic disease in patients with colorectal cancer.

There are a number of possible mechanisms by which this could occur. Firstly, that an elevated C-reactive protein identifies those patients with an impaired T-lymphocytic response, since poor infiltration of gastrointestinal tumours appears to be associated with poor outcome (Jass et al, 1987; Nielsen et al, 1999) and an elevated C-reactive protein concentration has recently been shown to be inversely associated with T-lymphocyte subset infiltration (Canna et al, 2005). An alternative explanation is that an elevated C-reactive protein concentration may identify those patients with a proangiogenic environment, since increased angiogenesis is associated with poor outcome in patients with colorectal cancer (Salmon et al, 2005) and circulating concentrations of vascular endothelial growth factor are directly associated with C-reactive protein (Xavier et al, 2006). Clearly, both these inflammatory mechanisms may be related and promote unrestrained tumour growth and the dissemination required for the greater malignant potential associated with an elevated C-reactive protein concentration.

In the present study, an elevated C-reactive protein concentration also predicted poor outcome in those patients receiving adjuvant 5-FU-based chemotherapy. However, it has long been recognised that progressive weight loss is associated with poor tolerance to chemotherapy. For example, Andreyev et al (1998) in a study of over 1500 patients who were to receive chemotherapy for gastrointestinal cancer showed that prior weight loss was an independent prognostic factor, and patients with weight loss received less chemotherapy and developed more dose-limiting toxicity. They concluded that there was a need to conduct nutritional intervention studies in these patients.

More recently, it has been shown that the presence of an ongoing systemic inflammatory response, as evidenced by an elevated C-reactive protein concentration, predicts the progressive nutritional decline of the patient with advanced gastrointestinal cancer (Lundholm et al, 1994; McMillan et al, 1999; O'Gorman et al, 1999). Moreover, recent work has shown that the activity of the enzyme cytochrome P450 3A, which is involved in the biotransformation of more than half of all drugs currently available, is compromised in patients with an elevated C-reactive protein concentration (Rivory et al, 2002; Slaviero et al, 2003; Baker et al, 2004). It may therefore be that there is a need to carry out studies to moderate the systemic inflammatory response rather than nutritional intervention in patients receiving chemotherapy.

Irrespective of the mechanisms involved, we believe that the presence or absence of a systemic inflammatory response should be evaluated as a possible influence on outcome in future trials of adjuvant chemotherapy in patients with colorectal cancer and should be used in the stratification of patients. This is however a small study and further larger studies are required to confirm these results.

In summary, the presence of a systemic inflammatory response appears to be an independent predictor of poor outcome in patients receiving adjuvant 5-FU-based chemotherapy following potentially curative resection for colorectal cancer.

\section{REFERENCES}

Andreyev HJ, Norman AR, Oates J, Cunningham D (1998) Why do patients with weight loss have a worse outcome when undergoing chemotherapy for gastrointestinal malignancies? Eur J Cancer 34: 503-509

Baker SD, van Schaik RH, Rivory LP, Ten Tije AJ, Dinh K, Graveland WJ, Schenk PW, Charles KA, Clarke SJ, Carducci MA, McGuire WP, Dawkins F, Gelderblom H, Verweij J, Sparreboom A (2004) Factors affecting cytochrome P-450 3A activity in cancer patients. Clin Cancer Res 10: $8341-8350$

Benson III AB, Schrag D, Somerfield MR, Cohen AM, Figueredo AT, Flynn PJ, Krzyzanowska MK, Maroun J, McAllister P, Van Cutsem E, Brouwers M, Charette M, Haller DG (2004) American Society of Clinical Oncology recommendations on adjuvant chemotherapy for stage II colon cancer. J Clin Oncol 22: 3408-3419

Bromwich E, McMillan DC, Lamb GW, Vasey PA, Aitchison M (2004) The systemic inflammatory response, performance status and survival in patients undergoing alpha-interferon treatment for advanced renal cancer. Br J Cancer 91: 1236-1238

Canna K, McArdle PA, McMillan DC, McNicol AM, Smith GW, McKee RF, McArdle CS (2005) The relationship between tumour T-lymphocyte infiltration, the systemic inflammatory response and survival in patients undergoing curative resection for colorectal cancer. $\mathrm{Br} J$ Cancer 92: $651-654$

Cascinu S, Georgoulias V, Kerr D, Maughan T, Labianca R, Ychou M (2003) Colorectal cancer in the adjuvant setting: perspectives on treatment and the role of prognostic factors. Ann Oncol 14(Suppl 2): ii25-ii29
Cengiz M, Akbulut S, Atahan IL, Grigsby PW (2001) Acute phase response during radiotherapy. Int J Radiat Oncol Biol Phys 49: $1093-1096$

Dukes CE, Bussey HJR (1958) The spread of rectal cancer and its effect on prognosis. Br J Cancer 12: 309-320

Forrest LM, McMillan DC, McArdle CS, Angerson WJ, Dunlop DJ (2004) Comparison of an inflammation-based prognostic score (GPS) with performance status (ECOG) in patients receiving platinum-based chemotherapy for inoperable non-small-cell lung cancer. Br J Cancer 90: $1704-1706$

Jass JR, Love SB, Northover JM (1987) A new prognostic classification of rectal cancer. Lancet 1(8545): $1303-1306$

Koc M, Taysi S, Sezen O, Bakan N (2003) Levels of some acute-phase proteins in the serum of patients with cancer during radiotherapy. Biol Pharm Bull 26: 1494-1497

Lundholm K, Gelin J, Hyltander A, Lonnroth C, Sandstrom R, Svaninger G, Korner U, Gulich M, Karrefors I, Norli B (1994) Anti-inflammatory treatment may prolong survival in undernourished patients with metastatic solid tumors. Cancer Res 54: 5602-5606

McArdle CS, Hole DJ (2002) Outcome following surgery for colorectal cancer: analysis by hospital after adjustment for case-mix and deprivation. Br J Cancer 86: $331-335$

McMillan DC, Canna K, McArdle CS (2003) A systemic inflammatory response predicts survival following curative resection for colorectal cancer. Br J Surg 90: 215-219 
McMillan DC, Wigmore SJ, Fearon KC, O'Gorman P, Wright CE, McArdle CS (1999) A prospective randomized study of megestrol acetate and ibuprofen in gastrointestinal cancer patients with weight loss. Br J Cancer 79: $495-500$

McMillan DC, Wotherspoon HA, Fearon KC, Sturgeon C, Cooke TG, McArdle CS (1995) A prospective study of tumor recurrence and the acute-phase response after apparently curative colorectal cancer surgery. Am J Surg 170: 319-322

Nielsen HJ, Christensen IJ, Sorensen S, Moesgaard F, Brunner N (2000) Preoperative plasma plasminogen activator inhibitor type-1 and serum C-reactive protein levels in patients with colorectal cancer. The RANX05 Colorectal Cancer Study Group. Ann Surg Oncol 7: $617-623$

Nielsen HJ, Hansen U, Christensen IJ, Reimert CM, Brunner N, Moesgaard F, The RANX05 Study Group (1999) Independent prognostic value of eosinophil and mast cell infiltration in colorectal cancer tissue. J Pathol 189: $487-495$

O'Connell MJ, Mailliard JA, Kahn MJ, Macdonald JS, Haller DG, Mayer RJ, Wieand HS (1997) Controlled trial of fluorouracil and low-dose leucovorin given for 6 months as postoperative adjuvant therapy for colon cancer. J Clin Oncol 15(1): 246-250
O'Gorman P, McMillan DC, McArdle CS (1999) Longitudinal study of weight, appetite, performance status, and inflammation in advanced gastrointestinal cancer. Nutr Cancer 35: $127-129$

O'Gorman P, McMillan DC, McArdle CS (2000) Prognostic factors in advanced gastrointestinal cancer patients with weight loss. Nutr Cancer 37: $36-40$

Rivory LP, Slaviero KA, Clarke SJ (2002) Hepatic cytochrome P450 3A drug metabolism is reduced in cancer patients who have an acute-phase response. $\mathrm{Br} J$ Cancer 87: $277-280$

Salmon JS, Lockhart AC, Berlin J (2005) Anti-angiogenic treatment of gastrointestinal malignancies. Cancer Invest 23: 712-726

Scottish Cancer Intelligence Unit (2000) Trends in Cancer Survival in Scotland 1971-1995 Information and Statistics Division. Edinburgh: Common Services Agency, pp 54-71

Slaviero KA, Clarke SJ, Rivory LP (2003) Inflammatory response: an unrecognised source of variability in the pharmacokinetics and pharmacodynamics of cancer chemotherapy. Lancet Oncol 4: 224-232

Xavier P, Belo L, Beires J, Rebelo I, Martinez-de-Oliveira J, Lunet N, Barros $\mathrm{H}$ (2006) Serum levels of VEGF and TNF-alpha and their association with C-reactive protein in patients with endometriosis. Arch Gynecol Obstet 273: $227-231$ 